\section{Epidural anaesthesia and analgesia do not affect energy expenditure after major abdominal surgery}

James M. Watters MD FRCSC,* Roderick J. March MD,* Dennis Desai MD, Kent Monteith MD, $†$ Jeffrey B. Hurtig MD FRCPC $\dagger$
Our objective was to determine the effect of perioperative epidural anaesthesia and analgesia on the increase in energy expenditure which accompanies major elective abdominal surgery in a prospective, randomized study. Eight patients undergoing elective resections of the colon and/or rectum received general anaesthesia alone (nitrous oxide, oxygen, and isoflurane, supplemented with intravenous fentanyl to a maximum of 10 $\mu \mathrm{g} \cdot \mathrm{kg}^{-1}$ ), and 12 patients received perioperative epidural anaesthesia and analgesia using lidocaine (carbonated lidocaine $2 \%$ with epinephrine 1:200,000,20 ml over $30 \mathrm{~min}$ ) and morphine (preservative-free morphine $0.10 \mathrm{mg} \cdot \mathrm{kg}^{-1}$ after catheter insertion and 0.05 to $0.10 \mathrm{mg} \cdot \mathrm{kg}^{-1}$ every $12 \mathrm{hr}$ as needed until the morning following surgery) via a lower lumbar catheter in addition to general anaesthesia. Respiratory gas exchange was measured using a metabolic cart and canopy system early on the morning of surgery, six hours postoperatively, and on the first and second postoperative mornings. Parenteral analgesic administration $(P<0.001)$ and visual analogue pain scores $(P<0.05)$ were lower in the patients receiving epidural anaesthesia and time to first parenteral analgesia was longer $(P<0.005)$. Oxygen consumption, carbon dioxide production, and energy expenditure increased afier surgery (all $P<0.001$ ) but were very similar in the two groups (all $P \geq 0.8$ ) before

\section{Key words}

ANALGESIA: postoperative;

ANAESTHETIC TECHNIQUES: epidural;

HORMONES: corticosteroids;

METABOLISM: oxygen consumption.

From the Departments of Surgery* and Anaesthesia†, University of Ottawa, Ottawa Civic Hospital, 1053 Carling

Avenue, Ottawa, Ontario, Canada KIY 4E9.

Address correspondence to: Dr. James M. Watters.

This work is supported by Medical Research Council of Canada Grant MT-10060. Dr. Watters is a Career Scientist of the Ontario Ministry of Health.

Accepted for publication 5th December, 1992. and after surgery. Despite substantial effects on postoperative pain, we conclude that oxygen consumption and energy expenditure following major abdominal surgery are not diminished by perioperative epidural anaesthesia and analgesia.

Notre intention est de déterminer l'effet de l'anesthésie et analgésie épidurales périopératoires sur l'accroissement de la dépense energétique qui accompagne une chirurgie abdominale majeure par une étude prospective et randomisée. Huit patients programmés pour des résections de colon et/ou de rectum reçoivent une anesthésie générale simple (protoxyde d'azote, oxygène et isoflurane, fentanyl intraveineux jusqu'à un maximum de $10 \mathrm{\mu g} \cdot \mathrm{kg}^{-1}$ ) et 12 patients reçoivent une anesthésie et une analgésie épidurale périopératoires avec de la lidocaïne (lidocaïne carbonatée $2 \%$ adrénalinée $1: 200000,20 \mathrm{ml}$ en trente minutes et de la morphine sans préservatif $0,10 \mathrm{mg} \cdot \mathrm{kg}^{-1}$ ) dès linsertion du cathéter et 0,05 à $0,1 \mathrm{mg} \cdot \mathrm{kg}^{-1}$ toutes les 12 heures au besoin jusqu'au lendemain de la chirurgie, par un cathéter lombaire bas en plus d'une anesthésie générale. Les échanges respiratoires sont mesurés sur un chariot utilitaire métabolique tôt le matin avant la chirurgie, six heures après la chirurgie puis le $1^{e}$ et le $2^{e}$ matins postopératoires. L'administration d'analgésique par voie parentérale (tous $P<0,001)$ et les résultats de l'échelle visuelle analogue de la douleur sont inférieurs chez les patients bénéficiant d'une anesthésie épidurale et le délai de la première analgésie parentérale est plus long $(P<0,005)$. La consommation d'oxygène, la production de $\mathrm{CO}_{2}$ et les dépenses énergétiques augmentent après la chirurgie (tous $P$ $<0,001)$, et de la même manière dans les dix groupes $(P \geq$ $0,8)$ avant et après la chirurgie. Malgré un effet substantiel sur la douleur postopératoire, nous concluons que la consommation d'O $\mathrm{O}_{2}$ et que la dépense d'énergie après une chirurgie abdominale majeure ne sont pas diminuées par une anesthésie et une analgésie péridurales.

The importance of afferent neural signals from the site of tissue injury to the central nervous system for the rapid initiation of endocrine responses was established by the animal studies of Hume, Egdahl and colleagues during 
the $1950 \mathrm{~s}^{1-3}$ More recently, neural blockade by epidural anaesthesia has been shown to minimize cortisol and other hormonal responses to lower abdominal and pelvic surgical procedures. ${ }^{4}$ While our understanding of the regulatory pathways which mediate host responses to acute surgical illness has evolved in recent years to include cytokines and other factors, recognition of the importance of afferent neural signals during and after elective surgery has continued. 5,6 The inhibition of such signals should minimize postoperative pain following major operation and could serve to limit increases in metabolic and cardiopulmonary demand. We hypothesized that the inhibition of afferent neural signals from the site of surgery by perioperative epidural anaesthesia and analgesia (using lidocaine and morphine) would minimize the metabolic responses to major elective abdominal surgical procedures. The purpose of this study was to determine the effect of epidural anaesthesia and analgesia on the increase in energy expenditure which accompanies resections of the colon and/or rectum.

\section{Methods}

Consecutive adult patients of either sex who were scheduled to undergo elective colorectal resection were eligible for study excluding those with a contraindication of epidural anaesthesia, diabetes mellitus, or receiving betaadrenergic blocking agents or corticosteroids. Patients known before laparotomy to have metastatic cancer were also excluded. The protocol was reviewed and approved by the Research Ethics Committee of the Ottawa Civic Hospital and informed, written consent was obtained from each patient.

Patients were randomized to receive perioperative epidural anaesthesia (EA $+\mathrm{GA}$ ) or not (GA alone) using sealed envelopes prepared from a table of random numbers. General anaesthesia in both groups was with nitrous oxide, oxygen, and isoflurane; supplementation was by intravenous fentanyl to a maximum of 10 $\mu \mathrm{g} \cdot \mathrm{kg}^{-1}$. Patients received supplemental neuromuscular blockade as required. Patients randomized to the epidural anaesthesia group had an epidural catheter inserted at the lower lumbar level by the attending anaesthetist prior to induction of general anaesthesia. Carbonated lidocaine $2 \%$ with epinephrine $(1: 200,000), 20 \mathrm{ml}$ over $30 \mathrm{~min}$, and preservative-free morphine $0.10 \mathrm{mg} \cdot \mathrm{kg}^{-1}$ were injected into the epidural space following insertion of a catheter and administration of a test dose of the lidocaine preparation. Mid-thoracic sensory level of anaesthesia was confirmed by pinprick. Additional lidocaine, $10 \mathrm{ml}$, was given every $90 \mathrm{~min}$ during the surgical procedure and once following surgery, $90 \mathrm{~min}$ after the previous dose. Patients randomized to the control group were managed in an entirely comparable manner with the exception that they did not have an epidural catheter inserted. All patients were transferred to the recovery room or intensive care unit from the operating room where they remained until the first postoperative day. The tracheas of all patients were extubated at the end of the surgical procedure or within the next four hours. Postoperative pain was managed in patients in the epidural group by the administration of epidural morphine 0.05 to $0.10 \mathrm{mg} \cdot \mathrm{kg}^{-1}$ once every $12 \mathrm{hr}$ as needed. Supplemental analgesia required by patients in either group was by parenteral morphine or demerol.

Respiratory gas exchange measurements were made using a metabolic cart and canopy system (Horizon System, SensorMedics, Anaheim California) on the afternoon before operation, at $7 \mathrm{a} . \mathrm{m}$. on the morning of operation, six hours after surgery, and at 7 a.m. on the first and second postoperative mornings. The first determination was intended to familiarize patients with the procedure, and that obtained on the morning of operation was taken as the preoperative (control) measurement. Measurements were made with the patient resting, supine, and in a quiet, semidarkened environment, over a ten minute steady state period following a period of equilibration. Peripheral venous blood was obtained at the same times for determination of serum cortisol. Postoperative pain was assessed using a visual analogue scale at the same postoperative times, and by noting parenteral narcotic requirements which are expressed in relation to demerol (demerol $100 \mathrm{mg}$ taken as equivalent to morphine $10 \mathrm{mg})^{?}$

Data are presented as mean $\pm S D$ and were analyzed by repeated measures analysis of variance and paired and unpaired $t$ tests using standard statistical software (Systat 5.1, Systat Inc, Evanston Illinois). Differences were to be considered significant when $P<0.05$.

\section{Results}

Eight patients were randomized to and received general anaesthesia alone (GA alone) and 12 epidural anaesthesia and analgesia in addition to general anaesthesia (EA + GA). Patients in the two groups were similar and underwent comparable surgical procedures (Tables I and II). All epidural catheters were judged clinically by the attending anaesthetist to be functioning well. The time to first parenteral analgesic administration was substantially longer in the epidural patients than in those receiving general anaesthesia alone (EA + GA, $881 \pm 582 \mathrm{~min}$, mean $\pm S D$, median 765 and range 300 to 1740 , versus GA alone, $27 \pm 20 \mathrm{~min}$, median 35 and range 0 to 50 , $P<0.005$ ). In addition, parenteral analgesia administration was less in the epidural group than in controls during the period of use of the epidural catheters, and visual analogue pain scores lower (Tables III and IV). 
TABLE I Patient characteristics

\begin{tabular}{lll}
\hline & $\begin{array}{l}\text { General } \\
\text { anaesthesia } \\
\text { alone }\end{array}$ & $\begin{array}{l}\text { General plus } \\
\text { epidural } \\
\text { anaesthesia }\end{array}$ \\
\hline$n$ & 8 & 12 \\
Age (yr) & $65 \pm 16$ & $64 \pm 11$ \\
Weight (kg) & $66.5 \pm 14.8$ & $68.3 \pm 17.1$ \\
Height (cm) & $167 \pm 14$ & $169 \pm 10$ \\
Body surface area (m²) & $1.73 \pm 0.21$ & $1.75 \pm 0.23$ \\
Sex (M:F) & $4: 4$ & $8: 4$ \\
Duration of procedure (min) & $203 \pm 60$ & $183 \pm 44$ \\
Metastatic cancer at laporotomy & 0 & 1 \\
\hline
\end{tabular}

TABLE IIl Parenteral analgesia

\begin{tabular}{lll}
\hline (mg demerol equivalents) & $\begin{array}{l}\text { Postoperative } \\
\text { day } 1\end{array}$ & $\begin{array}{l}\text { Postoperative } \\
\text { day } 2\end{array}$ \\
\hline General anaesthesia alone & $286 \pm 129$ & $225 \pm 76$ \\
General plus epidural anaesthesia* & $83 \pm 85$ & $283 \pm 91$ \\
\hline
\end{tabular}

$* P<0.001$ versus general anaesthesia alone by repeated measures ANOVA.
TABLE II Diagnoses and procedures

\begin{tabular}{lll}
\hline & $\begin{array}{l}\text { General } \\
\text { anaesthesia } \\
\text { alone }\end{array}$ & $\begin{array}{l}\text { General plus } \\
\text { epidural } \\
\text { anaesthesia }\end{array}$ \\
\hline $\begin{array}{l}\text { Diagnosis } \\
\text { Carcinoma colon or rectum }\end{array}$ & 6 & 12 \\
Other & 2 & 0 \\
$\begin{array}{l}\text { Procedure } \\
\text { Abdominoperineal resection }\end{array}$ & 4 & \\
Right hemicolectomy & 1 & 3 \\
Left hemicolectomy & 1 & 5 \\
Anterior resection rectosigmoid & 1 & 1 \\
Other & 1 & 2 \\
\hline
\end{tabular}

TABLE IV Visual analog pain scale score (mm)

\begin{tabular}{llll}
\hline & $\begin{array}{l}\text { Postoperative } \\
6 \text { hours }\end{array}$ & $\begin{array}{l}\text { Postoperative } \\
\text { day } 1\end{array}$ & $\begin{array}{l}\text { Postoperative } \\
\text { day 2 }\end{array}$ \\
\hline $\begin{array}{l}\text { General anaesthesia alone } \\
\text { General plus epidural }\end{array}$ & $60 \pm 43$ & $42 \pm 34$ & $40 \pm 25$ \\
anaesthesia* & $15 \pm 15$ & $27 \pm 21$ & $22 \pm 20$ \\
\hline
\end{tabular}

${ }^{*} P<0.05$ vs general anaesthesia alone by repeated measures ANOVA.

TABLE V Respiratory gas exchange

\begin{tabular}{|c|c|c|c|c|c|c|c|}
\hline & \multirow{2}{*}{$\begin{array}{l}\text { Pre- } \\
\text { operative }\end{array}$} & \multirow{2}{*}{$\begin{array}{l}\text { Post- } \\
\text { operative } \\
6 \text { hours }\end{array}$} & \multirow{2}{*}{$\begin{array}{l}\text { Post- } \\
\text { operative } \\
\text { day } 1\end{array}$} & \multirow{2}{*}{$\begin{array}{l}\text { Post- } \\
\text { operative } \\
\text { day } 2\end{array}$} & \multicolumn{3}{|c|}{$\begin{array}{l}\text { Percentage increase from preoperative } \\
\text { to postoperative }\end{array}$} \\
\hline & & & & & 6 hours & day 1 & day 2 \\
\hline \multicolumn{8}{|l|}{ Oxygen consumption $\left(\mathrm{ml}^{\cdot} \mathrm{min}^{-1}\right)$} \\
\hline General anaesthesia alone & $186 \pm 33$ & $225 \pm 73$ & $211 \pm 37$ & $220 \pm 66$ & $20 \pm 23$ & $14 \pm 11$ & $17 \pm 17$ \\
\hline General plus epidural anaesthesia* & $181 \pm 31$ & $224 \pm 61$ & $218 \pm 46$ & $213 \pm 51$ & $23 \pm 19$ & $20 \pm 10$ & $17 \pm 11$ \\
\hline \multicolumn{8}{|c|}{ Carbon dioxide production $\left(\mathrm{ml} \cdot \mathrm{min}^{-1}\right)$} \\
\hline General anaesthesia alone & $159 \pm 24$ & $181 \pm 45$ & $167 \pm 31$ & $170 \pm 48$ & $13 \pm 18$ & $6 \pm 14$ & $18 \pm 21$ \\
\hline General plus epidural anaesthesia $\dagger$ & $154 \pm 30$ & $183 \pm 53$ & $172 \pm 39$ & $170 \pm 41$ & $18 \pm 16$ & $11 \pm 13$ & $22 \pm 18$ \\
\hline \multicolumn{8}{|l|}{ Metabolic rate $\left(\mathrm{Kcal} \cdot \mathrm{m}^{-2} \cdot \mathrm{hr}^{-1}\right)$} \\
\hline General anaesthesia alone & $31.4 \pm 2.4$ & $37.2 \pm 7.8$ & $35.2 \pm 2.5$ & $36.0 \pm 6.6$ & $18 \pm 21$ & $13 \pm 11$ & $15 \pm 17$ \\
\hline General plus epidural anaesthesiaf & $30.2 \pm 2.7$ & $36.8 \pm 6.3$ & $35.8 \pm 4.1$ & $34.9 \pm 4.3$ & $22 \pm 18$ & $18 \pm 9$ & $15 \pm 10$ \\
\hline
\end{tabular}

${ }^{*} P=0.96, \dagger P=0.98, \ddagger P=0.79$ versus general anaesthesia alone by repeated measures ANOVA.

Oxygen consumption, carbon dioxide production, and metabolic rate increased following operation (all $P \leq$ $0.001)$ and there was no difference in responses between the two groups (all $P \geq 0.8$ ) (Table V). Body temperatures were similar in the two groups (Table VI). Serum cortisol concentrations increased following operation $(P<0.05)$ but with substantial variability and no statistically significant difference between the groups $(P=\mathrm{NS})$ (Table VII).

\section{Discussion}

There has been widespread interest in recent years in the use of epidural analgesia and anaesthesia for postoperative pain management and in their potential for reducing postoperative morbidity and mortality. 899 One randomized controlled trial of high-risk patients undergoing intraabdominal, intrathoracic, or major vascular procedures demonstrated a lower mortality and lower incidence of cardiovascular and major infectious compli- 
TABLE VI Body temperature $\left({ }^{\circ} \mathrm{C}\right)$

\begin{tabular}{lllll}
\hline & Preoperative & $\begin{array}{l}\text { Postoperative } \\
6 \text { hours }\end{array}$ & $\begin{array}{l}\text { Postoperative } \\
\text { day 1 }\end{array}$ & $\begin{array}{l}\text { Postoperative } \\
\text { day 2 }\end{array}$ \\
\hline General anaesthesia alone & $36.7 \pm 0.4$ & $36.9 \pm 0.6$ & $37.2 \pm 0.6$ & $37.1 \pm 0.4$ \\
General plus epidural anaesthesia* & $36.7 \pm 0.2$ & $37.0 \pm 0.8$ & $37.1 \pm 0.6$ & $37.1 \pm 0.5$ \\
\hline
\end{tabular}

* $P=$ NS vs general anaesthesia alone by repeated measures ANOVA.

TABLE VII Serum cortisol $\left(\mathrm{nmol} \cdot \mathrm{L}^{-1}\right)$

\begin{tabular}{lllll}
\hline & Preoperative & $\begin{array}{l}\text { Postoperative } \\
6 \text { hours }\end{array}$ & $\begin{array}{l}\text { Postoperative } \\
\text { day } 1\end{array}$ & $\begin{array}{l}\text { Postoperative } \\
\text { day 2 }\end{array}$ \\
\hline General anaesthesia alone & $429 \pm 229$ & $1013 \pm 369$ & $595 \pm 168$ & $487 \pm 190$ \\
General plus epidural anaesthesia* & $453 \pm 135$ & $690 \pm 366$ & $505 \pm 263$ & $476 \pm 184$ \\
\hline
\end{tabular}

* $P=$ NS vs general anaesthesia alone by repeated measures ANOVA.

cations in receiving epidural analgesia and anaesthesia with general anaesthesia compared with patients who received general anaesthesia alone. ${ }^{10} \mathrm{~A}$ review of 12 controlled trials comparing regional with general anaesthesia in patients undergoing surgery for hip fractures suggests a probable reduction in early postoperative mortality when data are pooled. ${ }^{8}$ Epidural anaesthesia consistently inhibits pituitary and adrenal responses to pelvic and lower extremity surgical procedures, endocrine responses which are closely related to metabolic responses including increased oxygen consumption. ${ }^{11-13}$ Since increased oxygen consumption may impose considerable demands on cardiopulmonary function which may, in turn, result in perioperative cardiac morbidity, the purpose of this study was to determine whether the modification of afferent neural signals by epidural anaesthesia and analgesia in patients undergoing major colorectal procedures would limit the expected increases in oxygen consumption and energy expenditure.

The epidural anaesthesia and analgesia used in this study was effective in terms of pinprick sensation prior to induction of general anaesthesia, and pain relief as assessed by a much longer time until the administration of parenteral analgesics in the epidural group, a lower parenteral analgesic dose during the first $24 \mathrm{hr}$ postoperatively, and lower visual analogue pain scores. The lack of suppression of neuroendocrine responses, indicated by the increase in serum cortisol in both groups, is consistent with other studies of various abdominal and other major procedures. ${ }^{10,14-16,17}$ Diminished serum cortisol responses in patient groups receiving epidural anaesthesia compared with controls have been reported in some instances ${ }^{14-16}$ but not in others. ${ }^{18,17}$ Yeager et al. observed a difference in urine cortisol excretion between epidural and control groups during the first $24 \mathrm{hr}$ postoperatively but not during the second $24 \mathrm{hr}$ or in serum cortisol at either of two postoperative time points. ${ }^{10}$ Carli et al. reported a marked rise in urine cortisol following elective colorectal procedures but no difference between patients receiving general anaesthesia with or without epidural anaesthesia. ${ }^{19}$ Potential explanations for the persistence of neuroendocrine responses despite the use of epidural techniques include incomplete blockade of afferent neural signals to the central nervous system from the site of surgery, initiation of neural signals from other sites in response to homeostatic perturbations, and the activation of other regulatory systems. Insufficient or absent blockade of phrenic, vagal, pelvic parasympathetic, and somatic afferents from the site of surgery and sympathetic afferents and efferent pathways have been postulated. ${ }^{20}$ Moreover, perturbations of core temperature, circulating volume, oxygenation, and acid-base status, even such as may occur during elective surgery, are sufficient to initiate neuroendocrine and metabolic responses via receptors and pathways unaffected by epidural blockade. Indeed the decrease in core temperature, relative hypovolaemia, and respiratory acidosis which may accompany epidural anaesthesia and narcotic administration would tend to increase oxygen consumption. ${ }^{21}$ Postoperative body temperature was very similar in our two groups; blood gas analyses were not performed routinely. Lastly, although elaboration of catecholamines and other "stress" hormones is related strongly to increased energy expenditure, activation of the classic neuroendocrine axis does not provide a complete explanation for the metabolic responses to surgical stress and our evolving understanding of cytokine and other mediators has led to studies of blocking agents such as indomethacin on the responses to surgery. ${ }^{22}$ The use of preoperative methylprednisolone, thoracic epidural bupivicaine and morphine, and indomethacin has been reported to result in improved pain relief and pulmonary function, and diminished prostaglandin 
$E_{2}$, interleukin-6, C-reactive protein and hyperthermic responses and fatigue following elective colon resection compared with controls given morphine and acetaminophen for postoperative analgesia. ${ }^{22}$

Despite the effectiveness of epidural anaesthesia and analgesia in terms of pain relief in this study and the variable modification of neuroendocrine responses here and elsewhere, oxygen consumption, carbon dioxide production, and metabolic rate increased following surgery in both groups and were very similar in the two groups, both preoperatively and from six hours to two days postoperatively. Potential explanations for the observed lack of any such difference, if it does exist, are the variability of the measurements and their timing. The variability of the changes in respiratory gas exchange following major operation is considerable in our data but similar to other reports. ${ }^{23-26}$ Sample size estimation based on the observed changes in oxygen consumption from preoperative values to six hours postoperatively, for example, and ignoring the repeated postoperative measurements, indicate the need to study more than $\mathbf{3 0 0}$ patients in total to detect a $25 \%$ difference between groups with probabilities of a type I error less than $5 \%$ and type II error less than $20 \%$. With the absence of any apparent difference between the two groups on repeated observations, it was not felt justified to attempt to study such a large number of patients.

Only limited data relating epidural anaesthesia and/ or analgesia to alterations in gas exchange following abdominal surgery are available elsewhere. Viale et al. studied oxygen uptake (by mass spectrometry) during combined epidural and general anaesthesia in 12 patients undergoing colorectal or gastric resections: during the first two hours postoperatively, six patients received epidural demerol while the other six patients were given subcutaneous morphine. ${ }^{27}$ Oxygen consumption was lower from 15 to $135 \mathrm{~min}$ postoperatively in the epidural demerol group but increased rapidly. Moreover, oxygen consumption decreased during operation compared with before operation and appeared to be similar to preoperative values at two hours postoperatively. Thus differences might have been discernable in our patients intraoperatively or early postoperatively had gas exchange measurements been made at those times but it is not clear that oxygen consumption and energy expenditure are substantially above preoperative levels in the immediate postoperative period in the absence of stimuli such as hypothermia. ${ }^{28}$ Diebel $e t$ al. have reported a lesser increase in oxygen consumption from before operation to the first day following aortic reconstruction in patients receiving combined general and epidural anaesthesia compared with general anaesthesia alone. ${ }^{29}$ However, the study was not randomized; the groups were not wholly comparable before surgery, and oxygen consumption was derived from thermodilution cardiac output measurements and arterial-mixed venous oxygen content differences.

Whether oxygen consumption and metabolic rate responses to major abdominal surgery are altered by epidural anaesthesia when other, longer-acting agents are used or are administered continuously is not known. However, in general, epidural techniques have had only limited effects on the metabolic responses to abdominal procedures in a variety of studies; only the addition of more "distal" blockade of the neuroendocrine axis, using etomidate and somatostatin, to thoracic epidural anaesthesia has largely prevented postoperative alterations in protein metabolism. ${ }^{13,16,30}$ The inhibition of the cortisol and other neuroendocrine responses to lower extremity and pelvic procedures by epidural techniques is much more complete than with more extensive abdominal procedures. ${ }^{8}$ We conclude from the present study that postoperative oxygen consumption and metabolic rate following major abdominal surgery are not consistently diminished by epidural anaesthesia and analgesia despite substantial reduction in postoperative pain.

\section{References}

1 Egdahl RH, Richards $J B$. The effect of stimulation of the femoral nerve on adrenal 17-hydroxycorticosteroid secretion in dogs. Surg Forum 1957; 7: 142-7.

2 Egdahl $R H$. Pituitary-adrenal response following trauma to the isolated leg. Surgery 1959; 46: 9-21.

3 Hume DM, Egdahl RH. The importance of the brain in the endocrine response to injury. Ann Surg 1959; 150: 697-712.

4 Christensen P, Brandt MR, Rem J, Kehlet H. Influence of extradural morphine on the adrenocortical and hyperglycaemic response to surgery. $\mathrm{Br} \mathrm{J}$ Anaesth 1982; 54: 23-7.

5 Kehlet $H$, Brandt MR, Rem J. Role of neurogenic stimuli in mediating the endocrine-metabolic response to surgery. JPEN J Parenter Enteral Nutr 1980; 4: 152-6.

6 Watters $J M$, Bessey $P Q$, Dinarello $C A$, Wolff $S M$, Wilmore $D W$. Both inflammatory and endocrine mediators stimulate host responses to sepsis. Arch Surg 1986; 121: 179-90.

7 Jaffe JH, Martin WR. Opioid Analgesics and Antagonists. In: Goodman Gilman A, Rall TW, Nies AS, Taylor $P$ (Eds.). The Pharmacological Basis of Therapeutics, 8th ed. New York: Pergamon, 1990.

8 Scott $N B$, Kehlet $H$. Regional anaesthesia and surgical morbidity. Br J Surg 1988; 75: 299-304.

9 Kehlet $H$. The surgical stress response: should it be prevented? Can J Surg 1991; 34: 565-7.

10 Yeager MP, Glass DD, Neff RK, Brinck-Johnsen $T$. 
Epidural anesthesia and analgesia in high-risk surgical patients. Anesthesiology 1987; 66: 729-36.

11 Wilmore DW, Long JM, Mason AD Jr, Skreen RW, Pruitt $B A J$ r. Catecholamines: mediator of the hypermetabolic response to thermal injury. Ann Surg 1974; 180: 653-9.

12 Bessey $P Q$ Watters $J M$, Aoki TT, Wilmore DW. Combined hormonal infusion simulates the metabolic response to injury. Ann Surg 1984; 200: 264-81.

13 Heindorff H, Schulze S, Mogensen T, Almdal T, Kehlet H, Vilstrup $H$. Hormonal and neural blockade prevents the postoperative increase in amino acid clearance and urea synthesis. Surgery 1992; 111 : 543-50.

14 Rutberg $H$, Håkanson E, Anderberg B, Jorfeldt L, Martensson $J$, Schildt $B$. Effects of the extradural administration of morphine, or bupivicaine, on the endocrine response to upper abdominal surgery. Br J Anaesth 1984; 56: 233-8.

15 Child CS, Kaufman L. Effect of intrathecal diamorphine on the adrenocortical, hyperglycaemic and cardiovascular responses to major colonic surgery. Br J Anaesth 1985; 57: 389-93.

16 Tsuji $H$, Shirasaka $C$, Asoh T, Uchida I. Effects of epidural administration of local anaesthetics or morphine on postoperative nitrogen loss and catabolic hormones. $\mathrm{Br} \mathrm{J}$ Surg 1987; 74: 421-5.

17 Schulze S, Roikjaer $O$, Hasselstrom L, Jensen NH, Kehlet $H$. Epidural bupivacaine and morphine plus systemic indomethacin eliminates pain but not systemic response and convalescence after cholecystectomy. Surgery 1988; 103 : 321-7.

18 Traynor C. Paterson JL, Ward ID, Morgan M, Hall GM. Effects of extradural analgesia and vagal blockade on the metabolic and endocrine response to upper abdominal surgery. Br J Anaesth 1982; 54: 319-23.

19 Carli F, Webster J, Pearson M, et al. Protein metabolism after abdominal surgery: effect of 24-h extradural blockade with local anaesthetic. Br J Anaesth 1991; 67: 729-34.

20 Kehlet $H$. Surgical stress: the role of pain and analgesia. Br J Anaesth 1989; 63: 189-95.

21 Kehlet $H$. Modification of responses to surgery by neural blockade: clinical implications. In: Cousins MJ, Bridenbaugh PO (Eds.). Neural Blockade in Clinical Anesthesia and Management of Pain. 2nd ed. Philadelphia: J B Lippincott, 1988: 145-88.

22 Schulze S, Sommer P, Bigler D, et al. Effect of combined prednisolone, epidural analgesia, and indomethacin on the systemic response after colonic surgery. Arch Surg 1992; 127: 325-31.

23 Hakkanson E, Rutberg H, Jorfeldt L, Wiklund L. Endocrine and metabolic responses after standardized moderate surgical trauma: influence of age and sex. Clin Physiol 1984; 4: 461-73.

24 Novick $W M$, Nusbaum $M$, Stein TP. The energy costs of surgery as measured by the doubly labeled water $\left({ }^{2} \mathrm{H}_{2}{ }^{18} \mathrm{O}\right)$ method. Surgery 1988; 103: 99-106.

25 Watters JM, Redimond ML, Desai D, March RJ. Effects of age and body composition on the metabolic responses to elective colon resection. Am Surg 1990; 212: 213-20.

26 Brandi $L S$, Frediani $M$, Oleggini $M$, et al. Insulin resistance after surgery: normalization by insulin treatment. Clin Sci 1990; 79: 443-50.

27 Viale JP, Annat GJ, Tissot SM, et al. Mass spectrometric measurements of oxygen uptake during epidural analgesia combined with general anesthesia. Anesth Analg 1990; 70: 589-93.

28 Roe CF, Goldberg MJ, Blair CS, Kinney JM. The influence of body temperature on early postoperative oxygen consumption. Surgery 1966; 60: 85-92.

29 Diebel LN, Lange MP. Schneider F, et al. Cardiopulmonary complications after major surgery: a role for epidural analgesia. Surgery 1987; 102: 660-6.

30 Brandt MR, Fernandes $A$, Mordhorst $R$, Kehlet $H$. Epidural analgesia improves postoperative nitrogen balance. BMJ 1978; 1: 1106-8. 